\title{
Molecular phylogenies, chromosomes and dispersion in Brazilian akodontines (Rodentia, Sigmodontinae)
}

\author{
Maria Claudene Barros ${ }^{1}$, Iracilda Sampaio ${ }^{2}$, Horacio Schneider ${ }^{2} \&$ Alfredo Langguth ${ }^{3}$ \\ 1. Laboratório de Genética e Biologia Molecular, CESC, Universidade Estadual do Maranhão, Praça Duque de Caxias S/N Bairro Alecrim, \\ 65604-000 Caxias, MA, Brazil. (claudene@ cesc.uema.br) \\ 2. Laboratório de Genética e Biologia Molecular, Núcleo de Estudos Costeiros, Universidade Federal do Pará, Av. Leandro Ribeiro s/n, \\ Aldeia, Bragança, PA, Brazil. (horacio@uol.com.br) \\ 3. Departamento de Sistemática e Ecologia, Universidade Federal do Paraíba, Campus Universitário, 58059-900 João Pessoa, PB, Brazil. \\ (boninomvd@hotmail.com)
}

\begin{abstract}
A new molecular phylogeny for akodontine rodents from Brazil was proposed. The phylogenetic tree was enriched with the area of occurrence and with information on the karyotype of the samples. Based on this enriched tree, and with a described methodology, hypotheses were proposed on the karyotype and area of occurrence of the ancestors of each Clade. Thus it was possible to discuss hypotheses on chromosome evolution of the group, and on dispersion events from the "area of original differentiation" of akodontines in the Andes. Chromosome evolution started with high diploid numbers $(2 \mathrm{n}=52)$ and showed a tendency to reduction (until $2 \mathrm{n}=14$ in more recent clades). Independent side-branches of the tree showed $2 \mathrm{n}$ reduction and in one case the $2 \mathrm{n}$ increased. At least four dispersion events from the Andes down to South-eastern Brazil were proposed. The results should suggest the direction of new studies on comparative karyology.
\end{abstract}

KEYWORDS. Brazilian akodontines, chromosome evolution, biogeography, molecular phylogeny.

RESUMO. Filogenia molecular, cromossomos e dispersão em akodontinos do Brasil (Rodentia, Sigmodontinae). Uma nova filogenia molecular para roedores akodontinos do Brasil é proposta. A árvore filogenética foi enriquecida com a área de ocorrência e com informações sobre o cariótipo das amostras. Baseado nisto, e com a metodologia descrita, foram propostas hipóteses sobre as características do cariótipo e sobre a área de ocorrência dos ancestrais de cada clado. Assim, foi possível discutir hipóteses sobre evolução cromossômica do grupo, e sobre eventos de dispersão a partir da área de diferenciação original dos akodontinos nos Andes. A evolução cromossômica começou com números diplóides altos $(2 n=52)$ e mostrou uma tendência a redução (até $2 n=14$ em clados mais recentes). Ramos independentes da árvore mostraram redução do $2 \mathrm{n}$ e num caso aumentou o numero diplóide. Foram propostos pelo menos quatro eventos de dispersão dos Andes até o Brasil Sul-Oriental. Os resultados indicam a direção de novos estudos em cariologia comparada.

PALAVRAS-CHAVE. Akodontinos do Brasil, evolução cromossômica, biogeografia, filogenia molecular.

Most of the South American cricetid rodents belong to an assemblage of genera usually grouped under the subfamily Sigmodontinae. According to the view originally proposed by HERSHKOVITZ $(1966,1972)$, and supported by SAVAGE (1974), ReIG $(1975,1978,1980,1981)$ and ENGEL et al. (1998), the North American ancestor entered South America through its northwestern corner by over water dispersal prior to the establishment of the Panamanian bridge, most probably between 5 and 9 MYA. This is the usually accepted hypothesis although there are some alternatives (see PARDIÑAs et al., 2002).

According to ReIG (1984) the original stock ancestral to Sigmodontinae may be found within the tribe Oryzomyini from which the Akodontini differentiated probably in the central Andean region. REIG (1986) considers that the ancestral akodontine may have been a generalized Akodonlike form of boreal origin, which colonized the area of the Puna from the north in Late Miocene or Early Pliocene, before the Altiplano reached considerable heights, in the Middle Pliocene (AhLFELD, 1970).

ReIG (1984) assumes that the evolution of Akodontini is a history of successful dispersion, certainly promoted by a trophic and habitat versatility of the most speciose genera such as Akodon Meyen, 1833 which became distributed over the greater part of South America, but prevailing in the Andean area.
To better understand the geographic history of the Sigmodontinae Reig (1984) introduced the concept of Area of Original Differentiation (AOD) as a tool to infer the patterns of geographical origin and of dispersion of the different groups of high Andean rodents. The AOD is defined as "the geographical space inside of which a certain taxon suffered its main differentiation (cladogenesis) in the subordinate taxa that compose it." In that sense, an AOD is not a "center of origin", since the ancestral lineage of a taxon that has a certain AOD does not have to be originated in the same area in which the taxon suffered its main differentiation processes. At the same time, the AOD of a taxon is the area where a new derived taxon originates by cladogenesis and that thereafter invades another area in which it suffers its main cladogenesis. This new area constitutes the AOD of the derived taxon. For the determination of the AOD of Akodontini, ReIG (1984) identified the area of greatest overlapping of the geographical distributions of the different species of this tribe. The data used were the records of distribution of each species, the frequency of a given taxon in a certain geographical unit, the analysis of the overlapping of the distribution of the genera in the area and also the percentage of endemic genera.

ReIG (1984) concluded that the South Central Andean Unit (SCA) and the North Southern Andean unit 
(NSA) are the regions of greatest occurrence of akodontine genera and subgenera (see a definition of these units in SIMPSON (1975) and REIG (1986)), suggesting that the akodontines probably differentiated in the intermediate zone between the SCA and the NSA.

REIG (1986) considers that to explain the present distribution of members of the Akodontini it may be necessary to assume that most of the taxa originated in what is now the southern Puna region (AOD), and that they migrated northwards, southwards and to the eastern lowlands and experienced there further differentiation.

We assume that akodontines of the Atlantic Forest or their ancestrals came from the AOD. The question rises: was it a single dispersion event with differentiation in the Atlantic Forest or several events? And when did it happen?

The diploid number of species of the genus Akodon s. l. varies from $2 \mathrm{n}=10$ in a sibling species of Akodon montensis Thomas, 1913 (SILVA \& YonENAGA-YASSUDA, 1998) to $2 \mathrm{n}=52$ in Thaptomys nigrita (Lichtenstein, 1829) and in other akodontine species of Southern South America. This karyotypic variation originated by several mechanisms including Robertsonian rearrangements, pericentric inversions, extranumerary chromosomes (YonENAGA et al., 1976; FAGUNDES et al., 1998).

To understand the karyotype evolution of akodontines it is necessary to know the direction of the chromosome rearrangements, toward fusion or fission. That is, if evolution proceeded from high to low diploid numbers by centric fusion or in the other direction by centromeric dissociation (BIANCHI et al., 1971; FAGUNDES et al., 1997; GEISE et al., 1998).

To determine this direction as well as plesiomorphic or apomorphic character states in karyotype, a reliable external phylogeny, morphological or molecular, is necessary.

Smith \& PATton (1993, 1999), Engel et al. (1998), Geise et al. (2001) and D'Elía (2003) addressed the question of the phylogeny of Sigmodontinae using sequences of the Cytochrome b gene of ${ }_{\mathrm{MT}} \mathrm{DNA}$. Fourteen species of Akodon of different geographical areas appeared in these author's cladograms as a monophyletic group with high bootstrap support.

In this paper we present a phylogenetic tree based on Cytochrome B sequences using new tissue samples and sequences taken from GenBank. Starting from Reig's theory of AODs (REIG, 1986), and with help of a molecular phylogeny, our aim is to propose new hypothesis on historical biogeography and chromosome evolution of eastern Brazilian species of Akodontini. This is probably the first study combining data from molecular phylogenies with information on karyotype and geographic distribution to understand aspects of karyotype evolution and geographic history of Brazilian akodontine rodents.

\section{MATERIAL AND METHODS}

Total DNA was obtained from grounded tissues of 20 samples belonging to eight species of the genus Akodon (Tab. I). Another 28 sequences were obtained from GenBank (Tab. I). Tissues were stored at the Laboratório de Citogenética de Mamíferos of the Departamento de Sistemática e Ecologia, Universidade Federal da Paraíba, and processed for DNA extraction (SAMBROOK et al., 1989) at the Laboratório de Genética e Biologia Molecular, Campus Bragança of the Universidade Federal do Pará. For each DNA sample a fragment of about 800 base pairs of the mitochondrial Cytochrome B gene was amplified and sequenced using primers described by SMITH \& PATTON (1993). Further details of the technique used may be found in BARRos et al. (2003).

The Cytochrome b gene fragment sequenced in this study was aligned to homologous sequences obtained from the GenBank using the ClustalX program (Thompson et al., 1997) with default parameters and the data converted to FASTA and NEXUS formats. Minor modifications in the alignment were made using the BIOEDIT sequence editor (HALL, 1999). Sequences were deposited in GenBank, accession numbers pending. Nucleotide saturation was assessed by plotting transitions and transversions against K2P distances (KIMURA, 1980) using the DAMBE program version 4.0.65 (XIA \& XIE, 2001). Phylogenetic reconstruction was performed using Maximum Parsimony, Neighbor-Joining and Minimum Evolution implemented in PAUP version 4.0b10 (SwOFFORD, 1998) and Mega version 2.0 (KuMAR et al., 2001). As outgroup we used Oryzomys (Hylaeamys) megacephalus (Fischer, 1814), a member of the sister group of the akodontines in the tree of D'Elía (2003).

The procedure used to reconstruct the chromosome evolution and the biogeographic history of Akodontini started from the concept of AOD, and from the need to polarize the chromosome rearrangements with help of an external molecular phylogeny. We formulated hypotheses to determine the diploid number and the geographic distribution of the most recent ancestral of the terminal units of the cladogram, repeating thereafter the procedure with the nearest ancestral toward the root of the tree. This information is than incorporated in the "enriched phylogenetic tree".

Once a phylogenetic tree was obtained we established for convention that the change of the character state, that is the anagenesis, occurred between the nodes of the tree and the nodes represent the ancestrals from which originated new taxa with different characteristics. The characters presented in table I and on the right side of figure 1 , correspond to the terminal taxa, and were used as a base to infer the characteristics of ancestrals. Since the characters of the terminal taxa are known, the characters of its more recent ancestral can be inferred. If all the terminal taxa of the clade considered possesses the same character state this will be attributed to its closest common ancestral. The same procedure was followed to determine the geographic distribution of the ancestral. When one of the terminal units of a certain clade occurs in the AOD, this distribution will be attributed to the ancestral of the whole clade because the basic hypothesis states that the dispersion is unidirectional starting from AOD. In that case, a dispersion event originated in the AOD may have occurred within this clade. Even if the collecting place of the studied specimen is not the AOD but the distribution of the species includes AOD we plotted for him AOD in the tree.

The hypothetical reconstruction of the ancestral will be made starting from the top of the tree. When the enriched tree is finished, reading the tree from the root allows to follow the evolutionary history of the group. 
Table I. Samples studied in this paper: identification (see Fig. 1), source of sequences (this paper or GenBank), karyotype of the species with source, and geographic origin ( ${ }^{1}$ Gardner \& Patton, 1976; ${ }^{2}$ Sbalqueiro et al., 1982; ${ }^{3}$ Bianchi \& Merani, 1984; ${ }^{4}$ Bianchi et al., $1971 ;{ }^{5}$ Myers et al., 1990; ${ }^{6}$ Sbalqueiro \& Nascimento, 1996; ${ }^{7}$ This paper; ${ }^{8}$ Myers \& Patton, 1989b; ${ }^{9}$ Geise et al., 2001; ${ }^{10}$ Patton, 1986; ${ }^{11}$ Myers, $1989 ;$

${ }^{12}$ Lobato et al., 1982; ${ }^{13}$ Margarete Mattevi pers. comm.; ${ }^{14}$ Cibele Bonvicino pers. comm.; ${ }^{15}$ Hsu \& BeniRshKe, 1973; ${ }^{16}$ Vitullo et al., 1986;

${ }^{17}$ Valéria P. Firme pers. comm.; ${ }^{18}$ Myers \& PAtton, 1989a; ${ }^{19}$ Reig, $1986 ;{ }^{20}$ Esbérard et al., 2005; ${ }^{21}$ ReIG et al., 1968; ${ }^{22}$ Reig et al., 1971;

${ }^{23}$ Yonenaga \& Ricci, 1969; ${ }^{24}$ Maia \& Langguth, 1981; ${ }^{25}$ Bonvicino et al., 1998; ${ }^{26}$ Freitas et al., 1984; ${ }^{27}$ D'Elí́a \& Pardiñas, 2004; ${ }^{28}$ Kasahara \& Yonenaga-Yassuda, 1984. *Probably all species of Brucepattersonius have the same karyotype that may be $2 \mathrm{n}=52$ since Bonvicino et al., 1997, 1998 described the chromosomes of B. griserufescens Hershkovitz, 1998 as having this diploid number).

\begin{tabular}{|c|c|c|c|}
\hline Sample identification & Source of sequence & Karyotype & Geographic origin of samples \\
\hline Akodon aerosus Thomas, 1913 & M35703 & $2 \mathrm{n}=22-40^{1}$ & Puno/Peru \\
\hline Akodon azarae (Fischer, 1829) & U03529 & $2 \mathrm{n}=38^{2,3,4}$ & Neembacu/Paraguay \\
\hline Akodon boliviensis Meyen, 1833 & M35691 & $2 \mathrm{n}=40^{4,5}$ & Puno/Peru \\
\hline Akodon cursor (Winge, 1887) 2 & this paper & $2 \mathrm{n}=14^{6}$ & Guaraqueçaba - PR Brazil \\
\hline Akodon cursor 3 & this paper & $2 \mathrm{n}=14^{7}$ & Faz. Amazonas - RJ/ Brazil \\
\hline Akodon cursor 4 & this paper & $2 \mathrm{n}=14^{7}$ & Faz. Amazonas - RJ/Brazil \\
\hline Akodon aff. cursor 1 & this paper & $2 \mathrm{n}=16^{7}$ & Caruaru - PE/Brazil \\
\hline Akodon aff. cursor 2 & this paper & $2 \mathrm{n}=16^{7}$ & Caeté, São Miguel - AL/Brazil \\
\hline Akodon aff. cursor 3 & this paper & $2 \mathrm{n}=16^{7}$ & Faz. Aldeia, Valença - BA/Brazil \\
\hline Akodon aff. cursor 4 & this paper & $2 \mathrm{n}=16^{7}$ & Sapé, PB/Brazil \\
\hline Akodon aff. cursor 5 & this paper & $2 \mathrm{n}=16^{7}$ & Sapé, PB/Brazil \\
\hline Akodon aff. cursor 6 & this paper & $2 \mathrm{n}=16^{6}$ & Guaraqueçaba - PR/Brazil \\
\hline Akodon aff. cursor 7 & this paper & $2 \mathrm{n}=16^{6}$ & Guaraqueçaba - PR/ Brazil \\
\hline Akodon juninensis Myers, Patton \& Smith, 1990 & M35698 & $2 \mathrm{n}=40^{5}$ & Junin/Peru \\
\hline Akodon kofordi Myers \& Patton, 1989 & M35697 & $2 \mathrm{n}=40^{8}$ & Puno/Peru \\
\hline Akodon lindberghi Hershkovitz, 1990 & AF184057 & $2 \mathrm{n}=42^{9}$ & Minas Gerais/Brazil \\
\hline Akodon mimus (Thomas, 1901) & M35710 & $2 \mathrm{n}=40^{10}$ & Puno/Peru \\
\hline Akodon molinae Contreras, 1968 & AY494839 & $2 n=42-44^{11}$ & Argentina \\
\hline Akodon mollis Thomas, 1894 & U03546 & $2 \mathrm{n}=22^{3,12}$ & Puno/Peru \\
\hline Akodon montensis Thomas, 19131 & this paper & $2 \mathrm{n}=24^{7}$ & Itatiaia - RJ/Brazil \\
\hline Akodon montensis 2 & this paper & $2 \mathrm{n}=24^{13}$ & Torres - RS/Brazil \\
\hline Akodon montensis 3 & this paper & $2 \mathrm{n}=24^{14}$ & Faz. Intervales - SP/Brazil \\
\hline Akodon montensis 4 & this paper & $2 \mathrm{n}=24^{13}$ & Torres - RS/Brazil \\
\hline Akodon mystax Hershkovitz, 1998 & this paper & $2 \mathrm{n}=42^{7}$ & Caparaó - ES/ Brazil \\
\hline Akodon orophilus Osgood, 1913 & M35699 & $2 \mathrm{n}=26^{15}$ & Amazonas/Peru \\
\hline Akodon puer Thomas, 1902 & M35693 & $2 \mathrm{n}=34^{16}$ & Puno/Peru \\
\hline Akodon reigi González, Langguth \& Oliveira, 1998 & 8 this paper & $2 \mathrm{n}=44^{17}$ & Itatiaia - RJ/Brazil \\
\hline Akodon serrensis Thomas, 19021 & this paper & $2 \mathrm{n}=46^{7}$ & Macaé - RJ/Brazil \\
\hline Akodon serrensis 2 & this paper & $2 \mathrm{n}=46^{7}$ & Caparaó - ES/ Brazil \\
\hline Akodon siberiae Myers \& Patton, 1989 & U03548 & $2 \mathrm{n}=38^{18}$ & Cochabamba/Bolivia \\
\hline Akodon subfuscus Osgood, 1944 & M35695 & $2 \mathrm{n}=40^{5}$ & Arequipa/Peru \\
\hline Akodon toba Thomas, 1921 & U03527 & $2 \mathrm{n}=40^{19}$ & Presidente Hayes/Paraguay \\
\hline Akodon torques Thomas, 1917 & M35700 & $2 \mathrm{n}=22-24^{10}$ & Cusco/Peru \\
\hline Blarinomys breviceps (Winge, 1887) 1 & AY 275112 & $2 \mathrm{n}=28^{20}$ & not given \\
\hline Blarinomys breviceps 2 & AF108668 & $2 \mathrm{n}=28^{20}$ & Estação Experimental Djalma Bahia - BA/Brazil \\
\hline Brucepatersonius iheringi (Thomas, 1896) & AF108667 & $2 \mathrm{n}=52^{*}$ & not given \\
\hline Brucepatersonius soricinus Hershkovitz, 1998 & AY277486 & $2 \mathrm{n}=52 *$ & Estação Biológica de Boracéia - SP/Brazil \\
\hline Necromys urichi (J. A. Allen \& Chapman, 1897) & U03549 & $2 \mathrm{n}=18^{21,22}$ & T. F. Amazonas/Venezuela \\
\hline Necromys amoenus (Thomas, 1900) & M35712 & $2 \mathrm{n}=34^{1}$ & Puno/Peru \\
\hline Necromys lasiurus (Lund, 1840) 1 & U03528 & $2 \mathrm{n}=34^{23,24}$ & Presidente Hayes/Paraguay \\
\hline Necromys lasiurus 2 & this paper & $2 \mathrm{n}=34^{7}$ & Sapé - PB/Brazil \\
\hline Oryzomys megacephalus (Fischer, 1814) & U03538 & $2 \mathrm{n}=52^{1}$ & Cusco/Peru \\
\hline Oxymycterus dasytrichus (Schinz, 1821) & AF516665 & $2 \mathrm{n}=54^{25}$ & Tarituba - RJ/Brasil \\
\hline Oxymycterus judex (Thomas, 1909) & AF516661 & $2 \mathrm{n}=54^{25}$ & Teresópolis - RJ/Brazil \\
\hline Oxymycterus rufus (Fischer, 1814) & AF516669 & $2 \mathrm{n}=54^{25}$ & Villa del Carmen - San Luis/Argentina \\
\hline Scapteromys aquaticus Thomas, 1920 & AY275132 & $2 \mathrm{n}=32^{26}$ & not given \\
\hline Scapteromys tumidus (Waterhouse, 1837) & AY275133 & $2 \mathrm{n}=24^{26,27}$ & not given \\
\hline Thaptomys nigrita (Lichtenstein, 1829) & this paper & $2 \mathrm{n}=52^{28}$ & Caparaó - ES/Brazil \\
\hline
\end{tabular}




\section{RESULTS AND DISCUSSION}

Phylogenetic Tree. Three phylogenetic trees were constructed by the methods of Neighbor-Joining (NJ) (Fig. 1), Minimum Evolution (ME) and Maximum
Parsimony (MP). The topology of the taxa was similar in all of them in spite of the low bootstrap values for the basal clades. They differed however in the positions of two clades: Scapteromys Waterhouse, 1837 (clade II, Fig. 1) and A. mystax Hershkovitz, 1998 (clade VII, Fig. 1)

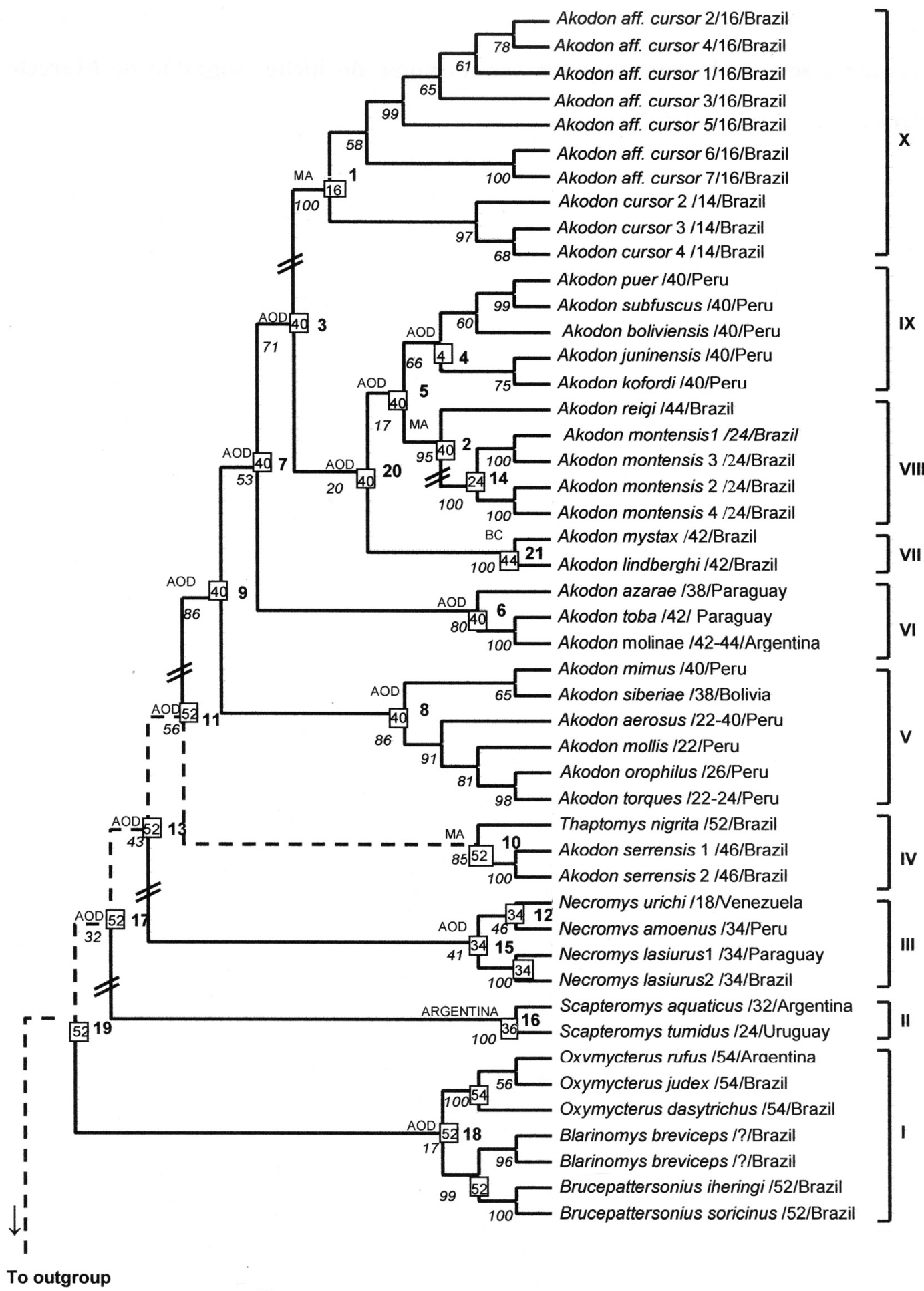

Figure 1. Phylogenetic tree obtained by the method of "Neighbor-Joining" considering genetic distances corrected by Kimura 2 parameters. The Roman numbers at right identify clades. For each sample is given: the species name followed by sample number when necessary; the diploid number between bars; the country of origin. The bootstrap values are indicated in italics below the branches. Bold numbers identify the ancestral of the clade (node). Inside the square the $2 \mathrm{n}$ is given. (AOD, area of original differentiation; MA, Atlantic Forest; BC, Central Brazil; //, chromosome revolution. Broken lines, lineages with ancestral karyotype). 
In ME and MP the Scapteromys clade is the first clade at the base of the cladogram, while in NJ Scapteromys forms the second clade and the first is formed by Brucepattersonius Hershkovitz, 1998 and Oxymycterus Waterhouse, 1837. In ME A. mystax is a sister group of $A$. reigi González, Langguth \& Oliveira, 1998 and $A$. montensis clade VIII. In MP A. mystax is a sister group of a large clade including clades VIII, IX and X (Fig. 1). This is a less parsimonious hypothesis and would imply in more dispersion events (see below).

The support for the older nodes in our topology is low, as is in the topology of SMITH \& PATTON (1993). D'ElíA (2003) grouped with high support $(\mathrm{JK}=100$ and $\mathrm{IB}=22)$ the akodontines Akodon, Deltamys Thomas, 1917, Necromys Ameghino, 1889, Thalpomys Thomas, 1916 and Thaptomys Thomas, 1916 (clade E). SMith \& PATTON (1999) presented a clade with Necromys, Thaptomys e Akodon with high support (BS=97). In our topology the grouping Akodon, Thaptomys and Necromys had low support (BS=43; node 13 (Fig. 1)).

In D'ElíA's (2003) study, Necromys groups with our clade IV while in our analysis Necromys is a sister group of all forms of Akodon s.s. but in both topologies support is low.

Smith \& PAtTon (1993) found a strong support $(\mathrm{BS}=100)$ for the ancestral node of the genus Akodon s.s., our topology shows a moderate support $(\mathrm{BS}=86$; node 9) and that from D'ELía (2003) presents low support (JK; 50 and $\mathrm{IB}=3$ ).

In our topology the basal genera, Brucepattersonius and Blarinomys Thomas, 1896 form a sister group of Oxymycterus (clade I). Scapteromys is a sister group of Necromys and Akodon with low support (BS=32, node 17). In D’ELÍA (2003) Scapteromys (clade A) occupies a more basal position being the sister group of Brucepattersonius and Blarinomys (clade B) but also with low support $(\mathrm{JK}<50, \mathrm{IB}=1)$. In his cladogram the genus Oxymycterus (clade C) is placed closer to Bibimys Massoia, 1979 (clade D) and Akodon (clade E) and not to the genera Brucepattersonius and Blarinomys as seen in our topology. In support of our topology of these basal clades is the agreement with hypotheses of high chromosome numbers in basal forms.

Karyotype evolution. As seen above, to understand the evolution of the karyotype and establish the direction of the evolution we compared karyotype data with the molecular phylogenetic tree.

Since most rearrangements of karyotype are consequence of Robertsonian changes and inversions the $2 \mathrm{n}$ and NA are useful tools to trace the chromosome evolution in a certain group. Some caviomorphs, for instance, show a remarkable constancy of NA with changes in $2 \mathrm{n}$. In sigmodontines both $2 \mathrm{n}$ and NA change. We work in our reconstruction of karyotype evolution with the diploid number alone but considering also, although not always explicitly, the size and number of arms in the whole karyotype. Primitive karyotypes in akodontines have large number of acrocentrics and derived karyotypes are formed in general by a smaller number of metacentrics usually consequence of centric fusions.

This tendency in akodontine rodents was suggested by several authors (VITULlo et al., 1986; REIG,
1987; GEISE et al., 1998) but changes may occur in both directions and only knowledge of the phylogeny of the group can establish the direction of change. Vitullo et al. (1986), based on other evidence, suggested that the ancestral $2 \mathrm{n}$ of akodontines was 58 .

In a general overview of the literature on akodontine karyotypes we observed that the differences among them may be the consequence of rearrangements. These rearrangements may be due to inversions or fusion/fission events of the whole karyotype or of large number of chromosomes ("chromosomal revolution") or to just a few Robertsonian changes in a few chromosomes ("low level chromosome diversification"). In establishing the ancestral karyotype of a clade we do not considered low level chromosome diversification. For instance $2 \mathrm{n}$ of 44 , 42 and 40 were all considered as $2 n=40$. In the following paragraphs we will comment the enriched tree (Fig. 1), clade by clade, starting from the root.

Clade I is the most basal in our phylogenetic tree with ancestral in node 19. It includes three ecologically similar oxymycterine genera inhabitants of the Atlantic Forest floor. Most of them share $2 n>52$ in agreement with Vitullo et al. (1986) hypothesis that larger $2 \mathrm{n}$ is primitive. On the line that leads to Blarinomys a chromosome revolution occurred resulting in strong reduction of $2 n$.

Clade II includes Kunsia tomentosus (Lichtenstein, 1829) as a sister group of Scapteromys aquaticus Thomas, 1920 and $S$. tumidus (Waterhouse, 1837) according to D’ElíA (2003). This clade derived from ancestral in node 17 , and suffered a chromosome revolution reducing the $2 \mathrm{n}$ to 44 in $K$. tomentosus (ANDRADES-MirANDA et al., 1999) and, later, a further reduction to $2 n=32$ and 24 in Scapteromys by low level diversification. It includes swamp and fossorial rats inhabitants of open country. As shown by Andrades-Miranda et al. (1999) no autosomes are shared by Kunsia Hershkovitz, 1966 and Scapteromys. Further, Scapteromys differed more widely from the ancestor scapteromyine than Kunsia.

Clade III, derived from ancestral $2 n=52$ in node 13, suffered also a chromosome revolution reducing the $2 \mathrm{n}$ to 34 , a rather stable karyotype of a genus of ample distribution in South America occupying open country from Venezuela to Argentina and Brazil. Its area of origin certainly was the AOD, because Necromys occurs today in this area. In D'ELíA (2003) tree Necromys is a sister group of the genus Thalpomys that has a similar karyotype and is also inhabitant of open country in Brazil.

The clade IV is formed by two species of forest dwellers of the Atlantic Forest and has the ancestral number 11 with an hypothetical karyotype of $2 n=52$. The $2 \mathrm{n}=52$ of $T$. nigrita is the old karyotype of node 19 . The $2 \mathrm{n}=46$ karyotype of $A$. serrensis Thomas, 1902 can be derived from the $2 \mathrm{n}=52$ of $T$. nigrita by low level chromosome diversification.

The area of occurrence of ancestral 10 is the Atlantic Forest of Southeast Brazil. A similar conclusion may be reached interpreting the tree of D'ElíA (2003).

Clade $\mathrm{V}$ derived from ancestral 9, includes a group with around $2 n=40$, with tendency to reduction in some members attaining a $2 n=22$. We suggest the $2 n=40$ for ancestral 8 because this number is also present in the 
sister clade (ancestral 7). The area of occurrence of ancestrals 9 and 8 would be the region of Peru and Bolivia included in the AOD since most species of the clade $\mathrm{V}$ occur in Peru.

The clade VI derives from ancestral 7 with $2 n=40$. This hypothesis is confirmed by the presence of karyotype $2 n=40$ in the neighboring clades. Members of the clade VI occur in lowlands of Brazilian Southeast, and Northern Argentina, Paraguay and Uruguay which are the probable areas of occurrence of the ancestral. In the clade VI the $2 n$ vary from 38 to 44 numbers derived by low level diversification from the ancestral 6.

The clade VII includes $A$. mystax with $2 \mathrm{n}=42$. This karyotype may be derived by low level diversification from an ancestral $2 \mathrm{n}-40$ in node 20

To check the position of $A$. mystax and $A$. reigi we prepared another tree including sequences in the GenBank used by Smith \& Patton (1993), Geise et al. (2001), D'Elía (2003) and specimens of $A$. reigi and $A$. mystax collected and identified by us. The result was: $[A$. reigi MNHN 3682, from Uruguay AY195865 D'ELía (2003). [A. paranaensis CIT 1131 from Venâncio Aires, RS AY195866 D'Elía et al.(2003). ["A. mistax" MN 48041, from Rio de Janeiro State AF184054 GEISE et al. (2001). [A. reigi from Itatiaia, RJ this paper. ["A. mistax" MN 48070 from Brejo da Lapa, Itatiaia, RJ AY273907 D’ELíA (2003)]]]]].

Except for the first clade the remaining clades had BS over 90 . We checked the identification of the "mystax" specimen MN 48070 (D'ELÍA, 2003) in the collection of the Museu Nacional do Rio de Janeiro, Brazil, it belongs to A. reigi. Akodon mystax MN 48041, from Rio de Janeiro State AF184054 GEISE et al. (2001) grouped with high bootstrap with our A. reigi, it was probably misidentified. Akodon paranaensis Christoff, Fagundes, Sbalqueiro, Mattevi \& Yonenaga-Yassuda, 2000 is on morphological grounds e junior subjective synonym of $A$. reigi. The degree of genetic divergence sometimes considered "moderate" and others "deep" by GONÇALVES et al. (2007) is not a taxonomic criterion to separate species.

As a result, the true $A$. mystax form a sister group of a clade formed by $A$. montensis and $A$. reigi. The $A$. lindberghi Hershkovitz, 1990 from GEISE et al. (2001) groups with $100 \% \mathrm{BS}$ with our specimen of $A$. mystax. According to GonçAlves et al. (2007) A. mystax and A. lindberghi are sister species that can usually be separated morphologically.

Clade VIII includes $A$. reigi $2 \mathrm{n}=44$ and $A$. montensis $2 n=24$. The phylogenetic line originated in node 2 suffered a karyotype revolution reducing drastically the $2 \mathrm{n}$. See GEISE et al. (1998) for details of chromosome shuffling.

Clade IX includes a group of Peruvian species with a shared $2 \mathrm{n}=40$, that is a sister group of the $A$. reigi $-A$. montensis assemblage of the Atlantic forest Akodon.

The clade $\mathrm{X}$ contains two parapatric sibling species A. cursor (Winge, 1887) $2 \mathrm{n}=14$ and $A$. aff. cursor $2 \mathrm{n}=16$ that form two monophyletic groups. Akodon cursor $2 \mathrm{n}=14$ showed an extensive polymorphism (YonENAGA, 1972; FAGUndes et al., 1998) and is distributed over the Southeastern part of the Brazilian Atlantic Forest. Akodon aff. cursor $2 \mathrm{n}=16$ show a restricted polymorphism (MAIA \& LANGguth, 1981) and is distributed over the
Northeastern part of the Brazilian Atlantic Forest with an enclave in the State of Paraná.

If the tendency was toward the reduction of the $2 n$, the ancestral 1 of the clade $X$ would have $2 n=16$ and may have occurred in the Atlantic forest of Southeastern Brazil.

The sister group of clade IV underwent between nodes 11 and 9 another chromosomal revolution reducing the $2 \mathrm{n}$ to around 40 chromosomes (38-44). This group suffered subsequent chromosome revolutions reducing independently the $2 \mathrm{n}$ to 14 (A. cursor) between nodes 1 and 3 on the one side and to 24 (A. montensis) between nodes 2 and 14 on the other side. These sister groups are genetically close (YonenaGa et al., 1975; FAGUNDEs et al., 1997) being sibling species but are not part of the same lineage, that is, the $2 \mathrm{n}=14$ species do not derived from the $2 \mathrm{n}=24$ form. Besides this, most Akodon clades showed low level differentiation the 2 n varying from 38 to 44 and in a few cases reducing gradually to $2 n=22$.

In the tree shown by D'ElíA (2003) and D'Elía et al. (2005) there is a clade below the T. nigrita-A. serrensis branch that includes the genus Bibimys, a sequence not available to us. Bibimys is very specialized morphologically and with an equally odd karyotype $2 n=70, N F=76$ or 80 (DyZENCHAUZ \& MASSARINI, 1999; GONÇALVES et al., 2005). This form probably derived by chromosomal revolution from an ancestral with $2 \mathrm{n}=52$. The tendency of karyotype evolution was in this case not to reduction but to increase of $2 \mathrm{n}$. This is the only plausible hypothesis. It will be interesting to study the mechanisms that lead to this higher chromosome number in Bibimys comparing his chromosome banding patterns with Brucepattersonius and T. nigrita. Certainly pericentric inversions followed by centric fissions worked out this karyotype, as is usually the case in species that increase de diploid number.

The ancestral 19 common to the group of the Oxymycterus-like mice and to the Akodon-like mice had probably a diploid number 52 in agreement with the hypothesis of Vitullo et al. (1986), this number (52) is present in the clade I.

Members of the clade I have a karyotype with diploid number 52-54 and its ancestral an Oxymycterus like form occupied the AOD.

In summary within the universe of species studied, chromosomal evolution started from high diploid numbers $2 \mathrm{n}=58$ according to VitUlLo et al. (1986) or $\mathrm{FN}=64$ as found in Oxymycterus, followed an evolutionary line of basic $2 \mathrm{n}=52$ from which derived at different times branches which reduced $2 \mathrm{n}$. This $2 \mathrm{n}$ reduction was probably the result of drastic chromosome repatterning events (chromosomal revolution).

Derived lines lead independently to reduction of $2 \mathrm{n}$ in Scapteromys, in Necromys, in ancestral Akodon, (node 40) in Akodon montensis, and in Akodon cursor. In these cases reduction of number was not simply consequence of centric fusion but involved also pericentric inversions. The general tendency to reduction was apparently reverted in the case of Bibimys.

Dispersion events from the AOD. Starting from the AOD, as defined by REIG (1986), several dispersion events may be suggested. The oldest one corresponds to the 
arrival of oxymycterines in Brazil (clade I). This was followed by the Scapteromys dispersal to eastern lowlands (clade II). The next dispersion event (clade III, Necromys) occurred over the lowlands of Argentina, Paraguay, Uruguay and Southern and Central Brazil as well as northwards to Venezuela. A new dispersal refers to members of clade IV (A. serrensis and A. nigrita), to the Atlantic Forest of Brazil. The next dispersion event refers to clade VI [A. azarae (Fischer, 1829) and A. molinae Contreras, 1968 etc.] over the lowlands of Argentina, Uruguay and Brazil. Ancestral of clades VII and VIII ( $A$. mystax, A. reigi and A. montensis) dispersed to the Atlantic Forest of Brazil. The last event refers to clade X formed by A. cursor and A. aff. cursor whose ancestral dispersed independently from the AOD to the Atlantic Forest.

Dating dispersion events. We used in our calculations the age of 3,55 My for the separation of Akodon from Necromys (node 13) as suggested by SмIтн \& PATTON (1993) to calibrate rates of ${ }_{\mathrm{MT}} \mathrm{DNA}$ sequence divergence at third position transversions. The estimates we obtained show that: ancestral 15 (Fig. 1) started a dispersion event of N. urichi (J. A. Allen \& Chapman, 1897) towards Venezuela 3,51 My ago. The ancestral 11 that gave origin to the first dispersion of Akodon to the Atlantic Forest has an age of 3,11 My. The ancestral 7 that originated the clade VI (A. toba Thomas, 1921, A. molinae and $A$. azarae) in Paraguay and Argentina has an age of 2,52 My. The ancestral 20 that gave origin to the second dispersion of Akodon to the Atlantic forest have an age of 1,82 My. The ancestral 5 that gave origin to the $A$. reigi $-A$. montensis group of the Atlantic forest of Brazil has an age of 1,77 My. The ancestral 3 that originated the $A$. cursor clade has 2,13 My.

These dates confirm that the events of dispersion and differentiation of the akodontines occurred mainly during the Pliocene.

As any hypothesis in science the picture of the evolution of Brazilian akodontines presented here will change with time. We hope that this paper stimulates further studies in comparative karyology, as well as sequencing of other genes or other taxa that will falsify present hypothesis.

Acknowledgments. We are obliged to Miguel Moreira, Valeria Pena Firme, Cibele Bonvicino, Ives Sbalqueiro, Margarete Mattevi, who generously provided tissue samples and to the different authors cited in the text who deposited in the GenBank the akodontine DNA sequences we used. We dedicate this study to Dr. James Patton for his continuous and generous effort to help development of Brazilian Mammalogy.

\section{REFERENCES}

Ahlfeld, F. 1970. Zur Tektonik des andinen Bolivien. Geolgisches Rundschau 59:1124-1140.

Andrades-Miranda, J.; Nunes, A. P.; Oliveira, L. F. P.; \& Mattevi, M. S. 1999. The karyotype of the South American rodent Kunsia tomentosus (Lichtenstein,1830). Cytobios 98:137-147.

Barros, M. C.; Sampaio, I. \& Schneider, H. 2003. Mitochondrial DNA data in sloths and anteaters. Genetics and Molecular Biology 26(1):5-11.

Bianchi, N. O. \& Merani, S. 1984. Cytogenetics of South American Akodont Rodents (Cricetidae). X. Karyological Distances at Generic and Intergeneric Levels. Journal of Mammalogy 65(2):206-219.
Bianchi, N. O.; Reig, O. A.; Molina, O. J. \& Dulout, F. N. 1971. Cytogenetics of the South American Akodont Rodents (Cricetidae). I. A progress Report of Argentinean and Venezuelan forms. Evolution 25:724-736.

Bonvicino, C. R.; Langguth, A.; Lindbergh, S. M. \& Paula, A. C. DE 1997. An elevational gradient study of small mammals at Caparaó national park, South eastern Brazil. Mammalia 61:547-560.

Bonvicino, C. R.; Penna-Firme, V. \& Seuánez, H. N. 1998. The karyotype of Brucepattersonius griserufescens. Hershkovitz, 1998 (Rodentia, Sigmodontinae) with comments on distribution and taxonomy. Zeitschrift für Säugetierkunde 63:329335.

D’Elía, G. 2003. Phylogenetics of Sigmodontinae (Rodentia, Muroidea, Cricetidae), with special reference to the akodont group, and with additional comments on historical biogeography. Cladistics 19:307-323.

D’Elía, G.; Gonzales, E. M. \& Pardiñas, U. F. J. 2003. Phylogenetic analysis of sigmodontine rodents (Muroidea), with special reference to the akodont genus Deltamys. Mammalian Biology 68:351-364.

D’Elía, G. \& Pardiñas, U. F. J. 2004. Systematics of Argentinean, Paraguayan, and Uruguayan swamp rats of the genus Scapteromys (Rodentia, Cricetidae, Sigmodontinae Journal of Mammalogy 85(5):897-910.

D’Elía, G.; Pardiñas, U. F. J. \& Myers, P. 2005. An introduction to the genus Bibimys (Rodentia: Sigmodontinae) phylogenetic position and alpha taxonomy. University of California Publications in Zoology 133:211-246.

Dyzenchauz, F. J. \& Massarini, A. I. 1999. First cytogenetic analysis of the genus Bibimys (Cricetidae, Rodentia). Zeitschrift für Säugetierkunde 64:59-62.

Engel, S. R.; Hogan, K. M.; TAYlor, J. F. \& Davis, S. K. 1998. Molecular Systematics and paleobiogeography of the South American sigmodontine rodents. Molecular Biology and Evolution 15:35-49.

Esbérard, C. E. L.; Sluys, M. V.; Rocha, C. F.; Geise, L. \& Bergallo, H. G. 2005. Cariótipo de Blarinomys breviceps (Winge, 1888) (Rodentia: Sigmodontinae) do Rio de Janeiro, com comentários sobre a sua morfologia e ecologia. In: CONGRESSO BRASILEIRO DE MASTOZOOLOGIA, 3, Aracruz, 2005, Anais... Vitória, Sociedade Brasileira de Mastozoologia. v.1, p. 103 .

Fagundes, V.; Christoff, A. U. \& Yonenaga-Yassuda, Y. 1998. Extraordinary chromosomal polymorphism with 28 different karyotypes in the Neotropical species Akodon cursor (Muridae, Sigmodontinae), one of the smallest diploid number in rodents $(2 \mathrm{n}=16,15$ and 14). Hereditas 129:263-274.

Fagundes, V.; Scalzi-Martin, J. M.; Sims, K.; Hozier, J. \& YonenaGAYASSUDA, Y. 1997. Zoo-Fish of a microdissection DNA library and G-banding patterns reveal the homeology between the Brazilian rodents Akodon cursor and A. montensis. Cytogenetics and Cell Genetics 78:224-228.

Freitas, T. R. O.; Mattevi, M. S. \& Oliveira, L. F. B. 1984. Unusual $\mathrm{C}$-band patterns in three karyotypically rearranged forms of Scapteromys (Rodentia, Cricetidae) from Brazil. Cytogenetics and Cell Genetics 38:39-44.

Gardner, A. L. \& Patton, J. L. 1976. Karyotypic variation in oryzomyine rodents (Cricetinae) with comments on chromosomal evolution in the Neotropical cricetine complex. Occasional Papers Museum Zoology Louisiana State University 49:1-48.

Geise, L.; Canavez, F. C. \& Seuánez, H. N. 1998. Comparative karyology in Akodon (Rodentia, Sigmodontinae) from Southeastern Brazil. Journal of Heredity 89:158-163.

Geise, L.; Smith, M. F. \& Patton, J. L. 2001. Diversification in the genus Akodon (Rodentia: Sigmodontinae) in southeastern South America: mitochondrial DNA sequence analysis. Journal of Mammalogy 82(1):92-101.

Gonçalves, P. R.; Myers, P.; Vilela, J. F. \& Oliveira, J. A. 2007. Systematics of species of the genus Akodon (Rodentia: Sigmodontinae) in Southeastern Brazil and implications for the biogeography of the campos de altitude. Miscellaneous Publications, Museum of Zoology, University of Michigan 197:1-24. 
Gonçalves, P. R. Oliveira, J. A.; Corrêa, M. O. \& Pessôa, L. M. 2005. Morphological and cytogenetic analyses of Bibimys labiosus (Winge, 1887) (Rodentia, Sigmodontinae): implications for its affinities with the scapteromyine group. University of California Publications in Zoology 133: $175-209$

Hall, T. A. 1999. BioEdit: a user-friendly biological sequence alignment editor and analysis program for Windows 95/98/ NT. Nucleic Acids Symposium Series 41:95-98.

Hershrovitz, P. 1966. South American swamp and fossorial rates of the scapteromyine group (Cricetinae, Muridae), with comments on the gland penis in murid taxonomy. Zeitschrift für Säugetierkunde 31:81-149.

1972. The recent mammals of the Neotropical Region: a zoogeographic and ecological review. In: Keast, A. F. C. E. \& Glass B. eds. Evolution, Mammals and Southern Continents. Albany, State University of New York. p.311-431.

Hsu, H. T. \& Benirshke, K. 1973. An atlas of Mammalian Chromosomes. New York, Springer Verlag. vol.7, p.102.

Kasahara, S. \& Yonenaga-Yassuda, Y. 1984. A Progress Report of Cytogenetic Data on Brazilian Rodents. Brazilian Journal of Genetics 7(3):509-533.

KimURA, M. 1980. A simple method for estimating evolutionary rate of base substitutions through comparative studies of nucleotide sequences. Journal of Molecular Evolution 16 : 111-120.

Kumar, S.; Tamura, K.; Jakobsen, I. B. \& Nei, M. 2001. MEGA2: Molecular Evolutionary Genetics Analysis software. Bioinformatics 17:1244-1245.

Lobato, L.; Cantos, G.; Araujo, B.; Bianchi, N. O. \& Merani, S. 1982. Cytogenetics of the South American akodont rodents (Cricetidae) X. Akodon mollis: a species with XY females and B chromosomes. Genetica 57:199-205.

MaiA, V. \& LangGuth, A. 1981. New karyotypes of Brazilian akodont rodents with notes on taxonomy. Zeitschrift für Saeugetierkunde 46:241-249.

Myers, P. 1989. A preliminary Revision of the varius Group of Akodon (A. dayi, dolores, molinae, neocenus, simulator, toba and varius). In: ReDFord, K. H. \& EIsenberG, J. F. eds. Advances in Neotropical Mammalogy. Gainesville, The Sandhill Crane. p.5-54.

Myers, P. \& Patton, J. L. 1989a. A new species of Akodon from the cloud forest of eastern Cochabamba Department, Bolivia (Rodentia: Sigmodontinae). Occasional Papers Museum Zoology University Michigan 720:1-28.

1989b. Akodon of Peru and Bolivia - Revision of the fumeus group (Rodentia: Sigmodontinae). Occasional Papers Museum Zoology University Michigan 721:1-35.

Myers, P.; Patton, J. L. \& Smith, M. F. 1990. A review of the boliviensis group of Akodon (Muridae: Sigmodontinae), with emphasis on Peru and Bolivia. Miscelaneous Publications Museum Zoology University Michigan 177:1-104.

Pardiñas, U. F. J.; D’Elía, G. \& Ortiz, P. E. 2002. Sigmodontinos fósiles (Rodentia, Muroidea, Sigmodontinae) de America del Sur: estado actual de su conocimiento y prospectiva. Mastozoologia Neotropical 9:209-252.

Patton, J. L. 1986. Patrones de Distribución y especiación de fauna de mamíferos de los Bosques Nublados Andinos Del Peru. Anales Museo Historia Natural Valparaíso 17:87-94.

ReIG, O. A. 1975. Diversidad, historia evolutiva y dispersión de los roedores cricétidos sudamericanos. Acta Científica Venezuelana 26 (Suppl. 1):7.

1978. Roedores cricétidos del Plioceno superior de la provincia de Buenos Aires (Argentina). Publicaciones Museo Municipal Ciencias Naturales Lorenzo Scaglia 2:164-190.

1980. A new fossil genus of South American cricetid rodents allied to Wiedomys, with an assessment of the Sigmodontinae. Journal of Zoology 192:257-281.

1981. Teoría del origen y desarrollo de la fauna de mamíferos de América del Sur. Monographiae Naturae Museo Municipal Ciencias Naturales Lorenzo Scaglia 1:1-161.
1984. Distribuição geográfica e história evolutivas dos roedores Muroideos sulamericanos (Cricetidae: Sigmodontinae). Revista Brasileira de Genética 7(2):333-365.

1986. Diversity Patterns and Differentiation of High Andean Rodents. In: Vuileumier, F. \& Monasterio, M. eds. High Altitude Tropical Biogeography. New York, Oxford University. p.404-439.

1987. An assessment of the systematics and evolution of the Akodontini, with the description of new fossil species of Akodon (Cricetidade Sigmodontinae). Fieldiana: Zoology 39:347-399

Reig, O. A.; Olivo, N. \& Kiblisky, P. 1968. Los cromosomas somáticos de Akodon urichi (Rodentia, Cricetidae). Acta Científica Venezuelana 19:73.

1971. The idiogram of the Venezuelan vole mouse, Akodon urichi venezuelensis Allen (Rodentia, Cricetidae). Cytogenetics 10:99-114.

Sambrook, J.; Fritsch, E. F. \& Maniatis, T. 1989. Molecular cloning: a laboratory manual. Cold Spring Harbor, Cold Spring Harbor Laboratory. p. 1659

SAvage, J. M. 1974. The isthmian link and the evolution of Neotropical mammals. Contributions Science Natural History Museum Los Angeles County 260:1-15.

Sbalqueiro, I. J.; Mattevi, M. S.; Oliveira, L. F. B. \& Freitas, T. R. O. 1982. Estudos cromossômicos de espécies de roedores akodontinos do Rio Grande do Sul. Ciência e Cultura 34:750.

Sbalqueiro, I. J. \& Nascimento, A. P. 1996. Ocurrence of Akodon cursor (Rodentia, Cricetidae) with 14, 15 and 16 chromosome cytotypes in the same geographic área in Southern Brazil. Brazilian Journal of Genetics 19(4):565-569.

Silva, M. J. DE J. \& Yonenaga-Yassuda, Y. 1998. Karyotype and chromosomal polymorphism of an undescribed Akodon from Central Brazil, a species with the lowest known diploid chromosome number in rodents. Cytogenetics Cell Genetics 81:46-50.

Simpson, B. B. 1975. Pleistocene changes in the flora of the high tropical Andes. Paleobiology 1:273-294.

Sмith, M. F. \& Patton, J. L. 1993. The diversification of South American murid rodents: evidence from mitochondrial DNA sequence data for the akodontine tribe. Biological Journal of the Linnean Society 50:149-177.

1999. Phylogenetic relationships and the radiation of sigmodontinae rodents in South America: Evidence from cytochrome b. Journal Mammalian Evolution 6:89-128.

Swofford, D. L. 1998. PAUP* Phylogenetic Analysis Using Parsimony (*and other Methods). Version 4 Sinauer Associates, Sunderland, Massachusetts.

Thompson, J. D.; Gibson, T. J.; Plewniak, F.; Jeanmougin, F. \& Higgins, D. G. 1997. The ClustalX windows interface: flexible strategies for multiple sequence alignment aided by quality analysis tools. Nucleic Acids Research 24:4876-4882.

Vitullo, A. D.; Merani, M. S.; Reig, A. O.; Kajon, A. E.; Scaglia, O.; Espinosa, M. B. \& Perez-Zapata, A. 1986. Cytogenetics of South American akodont Rodents (Cricetidae): New Karyotypes and Chromosomal Banding Patterns of Argentinian and Uruguayan Forms. Journal of Mammalogy 67:69-80.

XIA, X. \& XIE, Z. 2001. DAMBE: Data analysis in molecular Biology and evolution. Journal of Heredity 92:371-373.

Yonenaga, Y. 1972. Chromosomal polymorphism in the Akodon arviculoides $\mathrm{ssp} .(2 \mathrm{n}=14)$ resulting from two pericentric inversions. Cytogenetics 11:488-499.

Yonenaga, Y.; Frota-Pessoa, O.; Kasahara, S. \& Almeida, E. J. C. DE 1976. Cytogenetic Studies on Brazilian Rodents. Ciência e Cultura 28(2):202-211.

Yonenaga, Y.; Kasahara, S.; Almeida, E. J. C. \& Peracchi, A. L. 1975. Chromosomal banding patterns in Akodon arviculoides $(2 \mathrm{n}=14)$, Akodon sp. $(2 \mathrm{n}=24,25)$, and two male hybrids with 19 chromosomes. Cytogenetics Cell Genetics 15:388-399.

Yonenaga, Y. \& Ricci, F. 1969. Estudos cromossômicos em espécies de roedores. Ciencia e Cultura 21:249.

Recebido em janeiro de 2007. Aceito em abril de 2009. ISSN 0073-4721

Artigo disponível em: www.scielo.br/isz 